\title{
Indigenous Technological Capability in Developing Countries: A Preliminary Approach to Identification
}

\author{
M. M. HuQ*
}

\section{INTRODUCTION}

There are two important issues, though closely related, which follow from technology transfers. One of these refers to the appropriateness of imported technologies to the recipient countries and the other one refers to the development of indigenous technological capability. The first issue has already attracted close attention from a number of people including the present author. ${ }^{1}$ So far as the issue of indigenous technological capability in less developed countries (LDCs) is concerned, a major discussion centering round the topic took place at a conference held at the Centre of African Studies, University of Edinburgh, in May-June 1982. ${ }^{2}$ Although a number of important areas were debated in the above conference, no attempt was made to make any measurement of ITC achievement in LDCs, the theme of the present paper.

In an earlier article, the author had an opportunity to make observations on the use of indigenous and imported technologies in East and West Africa. ${ }^{3}$ The present article while making general observations on ITC achievement in developing countries will, however, make specific references to three countries of the Indian sub-continent - India, Pakistan and Bangladesh,

At the outset, it should be mentioned that in the discussion that follows there is a heavy emphasis on the development of the capital goods sector and, in particular, machinery and equipment. Such an emphasis may be criticized on the ground that we are ignoring first, the importance of the skills possessed by the labour force and

*The author is Assistant Professor at the University of Strathclyde, Glasgow U.K.

'See, for example, "David Livingstone Institute Series on Choice of Techniques in Developing Countries", which includes two industry studies by the author, M. M. Huq and H. Aragaw, Choice of Technique in Leather Manufacture, Scottish Academic Press, Edinburgh 1981 and M. M. Huq and C. C. Prendergast, Machine Tool Production in Developing Countries, Scott ish Academic Press, Edinburgh 1983.

${ }^{2}$ M. Fransman and K. King (eds.), Technolgoical Capability in the Third World, Macmillan, London 1984.

${ }^{3}$ M. M. Huq, "Use of imported and indigenous technologies - Observations from East and West Africa”, Science, Technology and Development (Vol. 4, No. 1), 1986. 
second, the importance of R \& D. It is, however, our belief that both the above elements are included in our approach as the ability of an LDC to produce and/or to use and maintain machinery and equipment will be largely dependent, among other things, on the skill level of its labour force and also on R \& D.

\section{MEASUREMENT DIFFICULTIES}

In a narrow sense, if the developing country concerned uses domestic machinery and equipment, rather than imported ones it is considered to have achieved ITC. Such a definition of ITC understandably implies autarky. It is, however, not necessary that a country be self-sufficient in the production of all machinery and equipment required. What is important is that, if necessary, it can produce the required machinery and equipment by using its capital goods sector and the technical know-how of its people. Indeed, all developed countries which possess ITC are big importers of machinery and equipment. ${ }^{4}$ This is so because in these countries there has developed specialization in the manufacture of machinery and equipment.

A country possessing a high level of ITC should also be able to adapt imported technologies to local circumstances and, in particular, maintain them without the help of foreign suppliers. To illustrate the point, let us take two items - power looms used in textile manufacturing and wooden drums used in leather manufacturing plants - which are produced in all the three countries from the Indian subcontinent mentioned above. ${ }^{5}$ In both these items, the relevant technologies (i.e. production methods) have been so acquired that even if these were imported, rather than produced at home, it would not create any difficulty to adapt them to local circumstances and also maintain them without depending on the foreign suppliers. In other words, the countries in the Indian sub-continent have achieved ITC in the case of the above. But it must be added that one cannot say so (i.e. achievement of ITC) once we start talking about higher level technologies.

Thus, in a broad sense, a country will have achieved ITC if it satisfies the following conditions: ${ }^{6}$

${ }^{4}$ For example, West Germany and the USA which are major producers of machine tools are also heavy importers of this type of machinery.

${ }^{5}$ I am grateful to Mr K. M. Nabiul Islam of Bangladesh Institute of Development Studies for raising this point.

${ }^{6}$ The definition has close similarity with that given by Frances Stewart: "What is indigenous technology? I take it to be a local capacity to create/adapt/modify technology. In other words, as well as the creation of some completely new technology, it includes the local development of technology already known elsewhere and the local modification of imported technologies". F. Stewart, "Facilitating Indigenous Technical Change in Third World Countries" in M. Fransman and K: King (eds.), op. cit., p. 81. (i) It is capable of producing the required machinery and equipment from its capital goods sector; and

(ii) It is able to adapt imported technologies to local circumstances and, if necessary, capable of maintaining them without depending on foreign suppliers.

There are, however, difficulties in providing a meaningful statistical definition which will enable us to measure whether a country has achieved ITC. It is like defining 'industrialization', as has been done by Sutcliffe, that "industrialization is the process by which a non-industrialized country becomes an industrialized one". Sutcliffe's approach to provide a satisfactory definition in this regard had to incorporate some arbitrary values for determining whether a country is industrialized or not: "a country 25 percent of whose GDP arose in the industrial sector, of which at least 60 percent was in manufacturing, and which had at least one-tenth of its population employed in industries would be counted as industrialized. Any country which did not satisfy these three criteria would not". The above arbitrary values taken by Sutcliffe can, of course, be criticized, but given the nature of the subject, it is rather difficult to avoid such an arbitrary measure.

A convenient approach to measuring ITC is to look at the contribution of the capital goods sub-sector in the manufacturing sector of an economy. In the initial stages of development, LDCs have been found to concentrate on the production of consumer goods. As development proceeds, the capital goods sector including transport equipment starts to develop. However, the process is not an automatic one. For those developing countries which are pursuing import substituting industrialization there is obviously scope for choice as to the development of particular items in the capital goods sector. The conscious decision to develop the capital goods sector as contained in the Indian growth strategy in the 1950s is an example in point. On the other hand, the consumption goods sector received preferential treatment in Pakistan's development strat egy.

Going back to the definition of ITC, one can perhaps consider some arbitrary values, as, for example, Sutcliffe did for defining whether a country is industrialized or not. If one-fifth of a country's manufacturing output is from the capital goods sub-sector it can possibly be considered to have achieved ITC. However, the manufacture of transport equipment is usually included in the capital goods sector and difficulties will arise if the assembly of transport equipment has gained exceptional prominence. For example, if one follows the classification of the manufacturing sectors into various sub-sectors, as shown in the World Development Report 1987, it is found that in Nigeria the machinery and transport equipment sub-sector has a 
share of 20 percent of the total manufacturing value added in the country. ${ }^{8}$ Given

Table 1

that the assembly of transport equipment has featured prominently in Nigeria's capital goods sub-sector, a definition of ITC without specifying the contribution of pure machinery and equipment will obviously create a problem. We would, therefore, like to add that at least two-thirds of the output of the capital goods sector should be in pure machinery and equipment for ITC achievement.

Thus, following the above approach, a country can be considered to have acquired ITC if its capital goods sector contributes at least one-fifth of the value of the total manufacturing output and, furthermore, if two-thirds of the total output of the capital goods sector is in the form of pure machinery and equipment.

Based on data provided in the World Development Report, mentioned above, an attempt is made below to make an analysis in terms of ITC achievement. As expected, one finds a positive correlation, though not a very strong one, between income per capita and capital goods value added as a percentage of the total manufacturing value added. ${ }^{9}$ With the exception of Ireland (18\%), New Zealand (17\%) and Australia (19\%), the capital goods sector in all the industrial market economies (a total of 19), shown in the source, contributed 20 percent or more of the total manufacturing value added in 1984. On the other hand, of the developing countries for which data are available, in only seven out of a total of 20 upper-middle countries and in only one out of a total of 33 low income developing countries did the capital goods sector succeed in generating 20 percent or more of the total value added in manufacturing. A further refinement, based on the contribution of pure machinery and equipment in the capital goods sub-sector will obviously be necessary for a meaningful identification of ITC achievement in these countries.

Data for individual countries are shown in Table 1. The table makes interesting reading especially because of the exceptions. For example, a country like India with low per capita income (US \$260 in 1984) has been able to achieve very good progress in machinery and transport equipment (19 percent of the total value added in manufacturing in 1984), an outcome of deliberate policy measures. On the other hand, in Pakistan which had a higher per capita income $(\$ 360)$ than in India (\$260), the corresponding figure was only 10 percent, while the figure for Bangladesh was still lower, only 6 percent.

${ }^{8}$ World Bank, World Development Report 1987.

${ }^{9}$ The following relationship was tried using 1984 data as shown in World Development Reports 1986 and 1987: Value added for machinery and equipment as a percentage of total value added in manufacturing was used as a dependent variable $(X)$ and GNP per capita as the independent variable $(Y)$. Value of the $Y$-coefficient is found to be statistically significant However, the explanatory power of the variable is not very strong, being able to explain only 51 percent of the variations. $(N=70)$.

GNP per Capita, Share of Manufacturing the GNP and Value-added in Machinery and Transport Equipment as a Percentage of Total Manufacturing Value added in various Countries of the World, 1984

\begin{tabular}{cccc}
\hline GDP per & Share of & Value-added in \\
Country & Capita & Manufacturing & Mans and \\
& (US \$) & in GDP $(\%)$ & As \% of Manufac- \\
& & & turing Value-added
\end{tabular}

\begin{tabular}{|c|c|c|c|c|}
\hline & (1) & (2) & (3) & (4) \\
\hline 1. & Bangladesh & 130 & 8 & 6 \\
\hline 2. & Mali & 140 & 7 & 6 \\
\hline 3. & Burma & 180 & 10 & 2 \\
\hline 4. & Tanzania & 210 & NA & 9 \\
\hline 5 . & Central African Republic & 260 & 8 & 1 \\
\hline 6. & India & 260 & 15 & 19 \\
\hline 7. & Kenya & 310 & 12 & 13 \\
\hline 8. & Ghana & 350 & 5 & 1 \\
\hline 9. & Sri Lanka & 360 & 14 & 4 \\
\hline 10. & Sudan & 360 & NA & 3 \\
\hline 11. & Pakistan & 380 & 20 & 10 \\
\hline 12. & Senegal & 380 & 18 & 7 \\
\hline 13. & Zambia & 470 & 21 & 10 \\
\hline 14. & Bolivia & 540 & 20 & 2 \\
\hline 15. & Indonesia & 540 & NA & 7 \\
\hline 16. & Ivory Coast & 610 & 17 & 8 \\
\hline 17. & Philippines & 660 & 25 & 8 \\
\hline 18. & Morocco & 670 & 17 & 4 \\
\hline 19. & Honduras & 700 & 15 & 1 \\
\hline 20. & El Salvador & 710 & 10 & 6 \\
\hline 21. & Egypt & 720 & NA & 13 \\
\hline 22. & Nigeria & 730 & 4 & 20 \\
\hline 23. & Zimbabwe & 760 & 27 & 9 \\
\hline 24. & Cameroon & 800 & 11 & 2 \\
\hline 25. & Nicaragua & 860 & 25 & 1 \\
\hline 26. & Thailand & 860 & NA & 12 \\
\hline 27. & Peru & 1000 & 25 & 12 \\
\hline 28. & Ecuador & 1150 & 19 & 1 \\
\hline 29. & Turkey & 1160 & 24 & 16 \\
\hline 30. & Paraguay & 1240 & 17 & 2 \\
\hline
\end{tabular}




\section{MANUFACTURE OF MACHINERY AND EQUIPMENT: DIRECT OBSERVATIONS}

The above approach of defining ITC in terms of the contribution of the capital goods sub-sector is obviously not very satisfactory, especially as arbitrary values have been assigned. An alternative approach is to examine the actual development of the engineering sector in individual LDCs. Following the four-stage classification of the development of the engineering industries, as identified by Huq and Prendergast, it is apparent that high level ITC achievement will take place at the final stage. It was, however, found that in the present state of engineering development, strictly speaking none of the LDCs has reached that state and only a handful of developing countries - e.g. Brazil, India, China, Argentina and Mexico - can be considered to have reached the third stage. ${ }^{10}$ "In the countries at this stage of development, the manufacture of industrial equipment and machinery in the total output remains lower than in the developed countries". ${ }^{11}$

Surprisingly, both India and China have very low per capita income, US \$260 and \$310 respectively in 1984 and, according to World Bank's classification, they are in the bottom category of the international income level. The fact that they have been able to make a significant improvement in capital goods development is largely due to the development strategy they have followed in this regard. On the other hand, the LDCs which have remained indifferent as to capital goods development have made very little progress in this regard.

Below we would like to incorporate the experience of three Asian countries India, Pakistan and Bangladesh - in the production of machinery and equipment for one particular product, leather manufacturing, an industry which has developed at a fast rate in all these three countries. The observations are based on the author's first-hand experience gained through personal contacts with a large number of leather manufacturers and also visits to many leather plants including leather machinery manufacturers.

Leather manufacturing has a long history in this part of the world. Indeed, vegetable tanned leather has been produced in the Indian sub-continent since the dawn of civilization. However, the development of chrome tanning is a product of Western industrial revolution, the production method of this type of leather finishing was invented in the late 19th century in the West. The leather manufacturing

${ }^{10}$ M. M. Huq and C. C. Prendergast, op. cit., p. 72. "The first stage covers the beginnings of the industry. Activity at this stage is confined to repair work and the production of simple metal products. At the second stage engineering industry will have begun to produce simple machinery and equipment. At the third stage the manufacture of industrial equipment and machinery expands and diversifies and the manufacture of machine tools becomes an important part of the industry. At the final stage, the engineering industry is fully developed". 
industry started growing rapidly in the early 1950s in both India and Pakistan and by the early 1980s, the industry was capable of processing the entire supply of local hides and skins up to the finished stage in both these countries. Bangladesh, which had a late start in manufacturing development, has also witnessed rapid growth in the industry, the entire supply of local hides and skins now being processed up to wet-blue and semi-finished crust leather and a small part even to finished leather for domestic use as well as for exports.

The technology required for the manufacture of leather is of a composite type, consisting of both simple and sophisticated machinery and equipment. Moreover, the method of production is such that there are distinctly separate work stations or sub-processes, thus enabling the leather producer to use machinery and equipment from different sources for different stages of production. Thus, the technology of leather manufacturing provides a good case for examining the degree and extent of the use of indigenous technology.

An area in which all the three countries mentioned above - India, Pakistan and Bangladesh - have invariably used local machinery is the wet stage operation with locally made wooden drums. The cost of production of local wooden drums is less than half the imported cost. So far as other machinery and equipment are concerned, Bangladesh has yet to make a serious mark, most of the machinery in this regard being almost entirely imported mainly from Italy, West Germany, England and Czechoslovakia, and a small part from Inida and France. Pakistan, which has a well developed leather manufacturing industry, also shows a heavy dependence on imported machinery, with very little use of locally produced machinery in non-wet stage operations. ${ }^{12}$ The Indian case is, however, significantly different in that the use of locally produced machinery has been increasing rapidly following the Indian Government's policy of providing positive encouragement for the use of local machinery, at times through high protection. It is, therefore, not surprising that the leather machinery industry has made rapid progress in India. The large market for leather machinery which exists in India has, of course, proved helpful for the industry, but it would be wrong to deny the strong role played by the government - through protection and other measures like making the leather plants justify the import of machinery - in the rapid development of leather machinery manufacturing in India.

\section{CONCLUSIONS}

Given the ready availability of machinery and equipment in the industrialized countries, there will be a natural tendency for a developing country to import

${ }^{12} \mathrm{~S}$. Moeenuddin, Industrialization in the NWFP: A Case Study of Leather Manufacturing, Unpublished M.Sc. thesis, University of Strathclyde, Glasgow 1985, pp. 67-9. technologies unless there exist substantial cost advantages in local manufacture, as for example in the case of wooden drums for leather manufacturing. The import of foreign machinery and equipment is likely to be further encouraged in a situation of aid dependence as in the case of Pakistan and Bangladesh.

For a developing country with low per capita income, the prospect of ITC achievement will remain low unless it takes a conscious decision, as has been done by India, to attain "technological competence and self-reliance". ${ }^{13}$ Such an objective, to have any real chance of success, however, needs to be backed up by policy measures aimed at reducing aid dependence. Considering that countries like Bangla desh and Pakistan have remained heavily dependent on aid, the chances of an early success in ITC do not appear very high in these cases.

${ }^{13}$ In a recent study on technology choice in Bangladesh, it has been found that enterprises with access to long-term credit, including foreign currency, tend to choose imported machinery and equipment, even if such items were locally available. So far as factors like experience of the investors, scale of production and export of output influencing the use of imported versus indigenous machinery are concerned, the relevant regression coefficients were not found statistically significant. The findings are based on an extensive survey of the leather manufacturing sector in Bangladesh. See M. M. Huq and K. M. Nabiul Islam, Choice of Technology: A Case Study of Leather Manufacturing in Bangladesh, Research Report No. 93, Bangladesh Institute of Development Studies, Dhaka 1989 (forthcoming). 


\section{Comments on}

"Indigenous Technological Capability in Developing Countries: A Preliminary Approach to Identification"

As only a preliminary draft was available for comment, the following remarks are themselves very preliminary. Also, not being an economist, I apologize if I misunderstood the contents of Dr Huq's trial paper. As a political scientist I certainly want to record at the outset my approval of Dr Huq's sensitivity about the importance of government in economic activity and the "policy focus" of his paper. My comments are therefore a series of questions that need to be addressed in subsequent drafts of his paper.

First, there is a definitional question: what, in fact, is "indigenous?" How does Huq disentangle the term from that which is not indigenous? In our global village, is the term really descriptive or denotative? Or is it connotative in an ideological sense? Of course, simplifying assumptions are always necessary (and welcome), but the author needs to spell them out. Like the caterpillar told Alice in Wonderland, "a word means exactly what I choose it to mean - no more and no less". So what is this term indigenous?

Second, logically a definition ought not contain the term being defined. Hence I am uneasy, even uncomfortable, with Sutcliffe's definition of industrialization because it seems tautological (cf page 3 of manuscript). Likewise, Huq's use of "capability" seems arbitrary. In any case, his preliminary approach to "indigenous technological capability" sounds perilously like an attempt to establish a world sweepstakes in approximate autarky. Is this the aim? Is autarky the goal? If so, make the statement (assertion) unambiguously

Third, what is "pure" machinery? Is it totally local fabrication versus the assembly of knocked-down kits (such as in audio-electronics)? How is "pure" measured? There are no tables on "pure" machinery in the paper nor any mention of indicators for the concept. At one point, the author does suggest that if the percentage of value added in total manufacturing exceeds 20 percent (one-fifth of industrial output), then a threshold has been crossed. But his argument is, at best, opaque.

Fourth, Huq asserts that a government policy of "import substitution" leads to (or at least encourages) "indigenous technological capability". By inference he approves of industrial policies that levy tariffs to protect nascent local industries. If this is indeed the case, he should spell out the causal linkage between policies and outcomes. Indeed, in his main case-study (the manufacture of leather products), Huq praises the "strong role played by government in India". What is this strong role? How does it influence leather manufactures?

Finally, to re-raise the question of autarky, the author implicitly prefers reduced dependence on aid. While emotionally appealing [since "independence" is a "good thing"], what are the side-effects of this reduced dependence? Are they all good? Are any effects bad? Or temporarily bad? Are there case examples (Burma comes immediately to mind) that suggest alternatives? In short, this draft paper by Huq raises some intriguing questions - but leaves the reader unsatisfied about answers, or even possible approaches to answers. But he is to be encouraged to continue explorations of the subject.

J. W. Björkman

American Studies Research Centre,

India 